WSRC-TR-2003-00193

Revision 0

\title{
Investigation of Plutonium and Uranium Precipitation Behavior with Gadolinium as a Neutron Poison
}

\author{
A. E. Visser, T. S. Rudisill, and M. G. Bronikowski
}

May 2003

Westinghouse Savannah River Company Aiken, SC 29808

Prepared for the U. S. Department of Energy under Contract DE-AC09-96SR18500 (mod. 68) 
This document was prepared in conjunction with work accomplished under Contract No. DE-AC09-96SR18500 with the U. S. Department of Energy.

\section{DISCLAIMER}

This report was prepared as an account of work sponsored by an agency of the United States Government. Neither the United States Government nor any agency thereof, nor any of their employees, makes any warranty, express or implied, or assumes any legal liability or responsibility for the accuracy, completeness, or usefulness of any information, apparatus, product or process disclosed, or represents that its use would not infringe privately owned rights. Reference herein to any specific commercial product, process or service by trade name, trademark, manufacturer, or otherwise does not necessarily constitute or imply its endorsement, recommendation, or favoring by the United States Government or any agency thereof. The views and opinions of authors expressed herein do not necessarily state or reflect those of the United States Government or any agency thereof.

This report has been reproduced directly from the best available copy.

Available for sale to the public, in paper, from: U.S. Department of Commerce, National Technical Information Service, 5285 Port Royal Road, Springfield, VA 22161, phone: (800) 553-6847, fax: (703) 605-6900

email: orders@ntis.fedworld.gov

online ordering: http://www.ntis.gov/help/index.asp

Available electronically at http://www.osti.gov/bridge

Available for a processing fee to U.S. Department of Energy and its contractors, in paper, from: U.S. Department of Energy, Office of Scientific and Technical Information, P.O. Box 62, Oak Ridge, TN 37831-0062,

phone: (865)576-8401,

fax: (865)576-5728

email: $\underline{\text { reports@ adonis.osti.gov }}$ 


\title{
Investigation of Plutonium and Uranium Precipitation Behavior with Gadolinium as a Neutron Poison
}

\author{
A. E. Visser, T. S. Rudisill, and M. G. Bronikowski \\ Westinghouse Savannah River Company \\ Aiken, SC 29808
}

\section{Summary}

Plutonium $(\mathrm{Pu})$-containing solutions currently stored in H-Canyon Tanks 12.1 and 16.3 do not meet acceptance criteria for conversion to a mixed oxide fuel. Therefore, the solutions will be neutralized and discarded to the Savannah River Site (SRS) high level waste (HLW) system. Prior to disposal, the addition of gadolinium nitrate $\left(\mathrm{Gd}\left(\mathrm{NO}_{3}\right)_{3}\right)$ as a neutron poison is proposed to allow neutralization of quantities of $\mathrm{Pu}$ greater than a minimum critical mass per neutralization batch. This disposition strategy was previously studied and used to discard approximately 100 $\mathrm{kg}$ of $\mathrm{Pu}$ to the HLW system. However, the current solutions have a distinct difference in composition from that material. These current solutions contain slightly enriched uranium (U), $0.8 \%{ }^{235} \mathrm{U}$, at concentrations equivalent to a $3: 1$ ratio with $\mathrm{Pu}$. The caustic precipitation behavior of $\mathrm{Pu}$-U-gadolinium (Gd) mixtures had not been previously investigated. Before implementation, the effect of $U$ on the precipitation would have to be evaluated to ensure that a sufficient quantity of $\mathrm{Gd}$ is always present in the precipitate slurry to ensure nuclear safety.

A sample of the Tank 12.1 solution was obtained to evaluate the precipitation behavior of $\mathrm{Pu}-\mathrm{U}-\mathrm{Gd}$ mixtures during caustic neutralization. Experiments were also performed using surrogate solutions containing $3 \mathrm{~g} / \mathrm{L} \mathrm{U}$ or $3 \mathrm{~g} / \mathrm{L} \mathrm{U}$ with $1 \mathrm{~g} / \mathrm{L} \mathrm{Pu}$. In each experiment, Gd was added to the acidic solutions as $\mathrm{Gd}\left(\mathrm{NO}_{3}\right)_{3}$ prior to neutralization with $50 \mathrm{wt} \%$ sodium hydroxide $(\mathrm{NaOH})$. Samples from the Tank 12.1 solution were neutralized in a step-wise manner to a $\mathrm{pH}$ of 4.5 and 7 to measure the $\mathrm{Pu} / \mathrm{Gd}$ ratio in the solids which formed prior to complete neutralization above $\mathrm{pH}$ 14. Subsequent experiments were performed in which samples from Tank 12.1 and surrogate solutions were neutralized to 1.2 and $3.6 \mathrm{M}$ excess hydroxide $\left(\mathrm{OH}^{-}\right)$. Samples of the precipitate slurry and supernate were then analyzed to evaluate the effect of $U$ on the precipitation.

During the neutralization experiments, the initial solids formed at $\mathrm{pH} 4.5$ in contrast to the previous studies on solutions in which solids were first observed at $\mathrm{pH} 3$. The formation of solids at the higher $\mathrm{pH}$ is consistent with the behavior of $\mathrm{U}$ solutions. At $\mathrm{pH} \mathrm{4.5,6 \%}$ of the $\mathrm{Gd}$ was found in the solids. This value is essentially the same as the $5 \%$ measured at $\mathrm{pH} 3$ in the previous studies. At $\mathrm{pH} 7$, at least $95 \%$ of the $\mathrm{Gd}, \mathrm{U}$, and $\mathrm{Pu}$ were removed from the solutions. Upon complete neutralization, greater than $99 \%$ of these elements were found in the precipitated solids. One week after neutralization, analysis of additional liquid and solid samples revealed no significant changes in composition. X-ray diffraction analysis confirmed the formation of sodium diuranate and gadolinium hydroxide in the solids after standing for one week. Scanning 
electron microscopy (SEM) detected $\mathrm{U}$ and $\mathrm{Pu}$ at all $\mathrm{pH}$ values and $\mathrm{Gd}$ at $\mathrm{pH} 7$ and $\mathrm{pH}$ values greater than 14 .

Thermal gravimetric analysis (TGA) of centrifuged solids indicated the ratio of $\mathrm{H}$ (from water) to $\mathrm{Pu}$ was 343:1 following neutralization to $3.6 \mathrm{M}$ excess $\mathrm{OH}^{-}$and 483:1 following neutralization to $1.2 \mathrm{M}$ excess $\mathrm{OH}^{-}$. These values greatly exceed the minimum $\mathrm{H}: \mathrm{Pu}$ ratio of $30: 1$ required for the use of $\mathrm{Gd}$ as a neutron poison for $1: 1 \mathrm{Gd}: \mathrm{Pu}$ by weight. Rheological properties of the precipitate slurry were also evaluated following neutralization. After one week without agitation, the precipitate solids were easily re-suspended in the supernate and settled to approximately $25 \%$ of the total volume in approximately 250 minutes. The apparent viscosity of the neutralized solution was equivalent to $4-6 \mathrm{M} \mathrm{NaOH}$; therefore, no problems in transferring the precipitate slurry are anticipated. Based on the results of these experiments, poisoning the $\mathrm{Pu}-\mathrm{U}$ solutions with $\mathrm{Gd}$ and subsequent neutralization is a viable means for discarding the $\mathrm{Pu}$ to the SRS HLW system.

\section{Introduction}

The HB-Line Phase I Facility is currently dissolving materials containing quantities of Pu which are excess to the Department of Energy needs. For solutions containing Pu with isotopic concentrations which meet specifications for mixed oxide (MOX) fuel, the Pu is dispositioned by conversion to an oxide and stored for subsequent fuel fabrication. In recent campaigns, $\mathrm{Pu}-$ containing solutions which did not meet fuel specifications were poisoned with Gd, neutralized, and dispositioned to the SRS HLW system for subsequent vitrification in the Defense Waste Processing Facility [1]. Approximately $35 \mathrm{~kg}$ of Pu are currently stored in H-Canyon tanks which do not meet fuel specifications. These solutions contain nominally $1 \mathrm{~g} / \mathrm{L} \mathrm{Pu}\left(88 \%{ }^{239} \mathrm{Pu}\right.$ and $\left.12 \%{ }^{240} \mathrm{Pu}\right)$ and $3 \mathrm{~g} / \mathrm{L}$ uranium $(\mathrm{U})\left(0.8 \%{ }^{235} \mathrm{U}\right)$ in $5 \mathrm{M}$ nitric acid $\left(\mathrm{HNO}_{3}\right)$. Poisoning these solutions with $\mathrm{Gd}$, neutralization to $1.2 \mathrm{M}$ excess hydroxide, and transfer to the HLW system was proposed as the disposition path for these materials.

Neutralization of H-Canyon solutions containing significant quantities of fissile material and transfer to the HLW system is accomplished with the addition of a neutron poison to ensure nuclear safety. Gd, depleted $\mathrm{U}$, iron, and manganese have been used to poison SRS process solutions prior to discarding to the HLW system. The use of Gd is preferred when large quantities of $\mathrm{Pu}$ are discarded. Gadolinium is very effective in capturing thermal neutrons; therefore, the amount of poison added to a solution is minimized compared to other poisons. Minimizing the mass of poison generates a smaller volume of HLW glass and is important in facilitating the transfer of the resulting precipitate slurry. The formation of large quantities of metal hydroxides upon neutralization can result in sludges which are difficult to suspend and transfer.

In the past, when Pu-containing solutions were poisoned with $\mathrm{Gd}$, neutralized, and discarded to the HLW system, the solutions contained very little U. It was hypothesized that, despite the presence of $3 \mathrm{~g} / \mathrm{L} \mathrm{U}$ in solution with $\mathrm{Pu}$, caustic precipitation of $\mathrm{Pu}$ with $\mathrm{Gd}$ as a neutron poison would remain a viable process for the treatment of this material. There are literature reports of precipitation in U-Gd systems and the poisoning behavior of Gd in solution with Pu. The U-Gd precipitates from the nitrate [2] and carbonate [3] salts were not examined and, instead, were 
heated to form the oxides. Poisoning of Pu with $\mathrm{Gd}$ [4] was performed in the presence of $4.1 \mathrm{M}$ $\mathrm{HNO}_{3}$ with no precipitation observed, despite maximum concentrations of $363 \mathrm{~g} / \mathrm{L} \mathrm{Pu}$ and 20 $\mathrm{g} / \mathrm{L} \mathrm{Gd}$.

In a caustic environment, $\mathrm{Pu}$ will precipitate and form polymeric materials or hydroxides [5-6]. In basic media, uranyl $\left(\mathrm{UO}_{2}{ }^{2+}\right)$ precipitates as a complex solid (e.g., sodium diuranate $\left(\mathrm{Na}_{2} \mathrm{U}_{2} \mathrm{O}_{7}\right)$ ) [5]. When $\mathrm{Gd}$ is present in solution prior to $\mathrm{Pu}$ precipitation, the precipitate will contain an intimate mixture of $\mathrm{Gd}$ and $\mathrm{Pu}$, both likely present as hydroxides [1]. However, there remains a minimal amount of information regarding characterization and precipitation behavior of $\mathrm{Pu}-\mathrm{U}-\mathrm{Gd}$ in caustic media.

The goal of the experiments performed and discussed in this report was to determine if the presence of a 3:1 ratio of $\mathrm{U}$ to $\mathrm{Pu}$ in these solutions would have a detrimental effect (e.g., Gd would no longer precipitate with $\mathrm{Pu}$ ) on caustic precipitation and if $\mathrm{Gd}$ could be used as a poison in this system.

\section{Experimental}

\section{Precipitation and Sampling}

Caustic precipitation experiments were performed using $25 \mathrm{~mL}$ aliquots of a $100 \mathrm{~mL}$ sample from H-Canyon Tank 12.1. The solution composition for elements of interest is summarized in Table 1. Neutralization experiments were also performed using $40 \mathrm{~mL}$ of surrogate solutions containing nominally $3 \mathrm{~g} / \mathrm{L} \mathrm{U}$ or $3 \mathrm{~g} / \mathrm{L} \mathrm{U}$ with $1 \mathrm{~g} / \mathrm{L} \mathrm{Pu}$. The solutions were prepared from reagent grade uranyl nitrate hexahydrate $\left(\mathrm{UO}_{2}\left(\mathrm{NO}_{3}\right)_{2} \cdot 6 \mathrm{H}_{2} \mathrm{O}\right)$ and a $40 \mathrm{~g} / \mathrm{L} \mathrm{Pu}$ solution previously purified by anion exchange. Unless otherwise indicated, all experiments were performed at ambient temperature.

Table 1: Composition of HB-Line Phase I

Tank 12.1 Solution

\begin{tabular}{ccc}
\hline \hline Element & Concentration $(\mathrm{mg} / \mathrm{L})^{(1)}$ \\
\hline & $\mathrm{Al}$ & 161 \\
& $\mathrm{~B}$ & 3130 \\
& $\mathrm{Fe}$ & 177 \\
& $\mathrm{Gd}$ & 1740 \\
& $\mathrm{Na}$ & 64.5 \\
& $239 / 240 \mathrm{Pu}$ & 1140 \\
& $\mathrm{U}$ & 3240 \\
\hline (1) & SRTC analysis. & \\
(2) & Added as a 30 wt\% $\mathrm{Gd}\left(\mathrm{NO}_{3}\right)_{3}$ solution.
\end{tabular}

To ensure a consistent $\mathrm{Gd}$ concentration in each experiment, a predetermined amount of $30 \mathrm{wt} \%$ $\mathrm{Gd}\left(\mathrm{NO}_{3}\right)_{3}$ solution was added to the $100 \mathrm{~mL}$ bottle containing the Tank 12.1 solution. A 1:1 $\mathrm{Pu}: G d$ mass ratio was targeted; although, the final ratio was nominally 1:1.5. An appropriate amount of the $30 \mathrm{wt} \% \mathrm{Gd}\left(\mathrm{NO}_{3}\right)_{3}$ solution was also added to the $3 \mathrm{~g} / \mathrm{L} \mathrm{U}$ surrogate and the $3 \mathrm{~g} / \mathrm{L}$ $\mathrm{U}$ with $1 \mathrm{~g} / \mathrm{L} \mathrm{Pu}$ surrogate solutions targeting 3:1 U:Gd and 1:3:1 Pu:U:Gd ratios. The actual 
ratios for the surrogate solutions were approximately 1.6:1 U:Gd (U surrogate) and 1:2.74:1.05 $\mathrm{Pu}: \mathrm{U}: \mathrm{Gd}(\mathrm{Pu}-\mathrm{U}$ surrogate).

The Tank 12.1 solution was transferred to $100 \mathrm{~mL}$ beakers using a graduated cylinder; a $5 \mathrm{~mL}$ pipette was used for the surrogate solutions to improve volume control. Each solution was neutralized to the desired endpoint (Table 2) by the drop-wise addition of $50 \mathrm{wt} \% \mathrm{NaOH}$ using a volumetric burette in increments such that the temperature of the solutions did not exceed $50^{\circ} \mathrm{C}$. The solutions were stirred using a magnetic stirring bar. Once the formation of solids was observed and/or the appropriate $\mathrm{pH}$ attained (as measured by $\mathrm{pH}$ paper, $\pm 0.5 \mathrm{pH}$ unit), the beakers were covered with Parafilm $\mathrm{M}^{\mathrm{TM}}$ and the solutions were stirred for 2-3 hours prior to sampling.

Table 2: pH Adjustment of Tank 12.1 Samples

\begin{tabular}{|c|c|c|}
\hline Sample ID & $\begin{array}{c}50 \% \text { (wt.) } \\
\mathrm{NaOH} \\
\text { Added (mL) }\end{array}$ & $\begin{array}{c}\text { Volume of } \\
\text { Solution } \\
\text { Neutralized }(\mathrm{mL})\end{array}$ \\
\hline $\mathrm{pH} 4.5^{*}$ & 8.2 & 25 \\
\hline $\mathrm{pH} 7$ & 8.1 & 25 \\
\hline pH $14\left(1.2 \mathrm{M} \mathrm{OH}^{-}\right)$ & 10.2 & 25 \\
\hline $\mathrm{pH} 14\left(3.6 \mathrm{M} \mathrm{OH}^{-}\right)$ & 13.9 & 25 \\
\hline U-surrogate (pH $\left.14 \& 1.2 \mathrm{M} \mathrm{OH}^{-}\right)$ & 14.0 & 40 \\
\hline Tank 12.1 Surrogate (pH $\left.14 \& 1.2 \mathrm{M} \mathrm{OH}^{-}\right)$ & 14.0 & 40 \\
\hline
\end{tabular}

"Tank 12.1 solution added with a graduated cylinder

While stirring, four $1.5 \mathrm{~mL}$ aliquots of the precipitate slurry were removed from each beaker and transferred into four $1.5 \mathrm{~mL}$ conical centrifuge tubes and centrifuged $(5000 \mathrm{~g}$ ) for $5 \mathrm{~min}$. Using two of the centrifuge tubes, aliquots of sufficient volume were removed from the supernate for ${ }^{238} \mathrm{Pu}$ and ${ }^{239 / 240} \mathrm{Pu}$ analysis (thenolyltrifluoroacetone (TTA) extraction), americium $\left({ }^{241} \mathrm{Am}\right)$ and ${ }^{241} \mathrm{Pu}$ measurements by gamma pulse height analysis (PHA), and U, boron (B), and Gd analysis by inductively coupled plasma emission spectroscopy (ICP-ES). For each ICP-ES sample, a $1 \mathrm{~mL}$ aliquot of the supernate or dissolved solids was diluted (1:9) with deionized water. The remaining supernate was then removed from the centrifuge tubes and the precipitate dissolved in $1 \mathrm{~mL}$ of $8 \mathrm{M} \mathrm{HNO}_{3}$. The aqueous phase was subsequently removed from the two remaining centrifuge tubes and a small amount of the precipitate was analyzed by x-ray diffraction (XRD), and SEM.

After the initial sampling, the beakers were covered with Parafilm $\mathrm{M}^{\mathrm{TM}}$ and allowed to stand for one week (without stirring) after which the sampling routine was repeated and a set of samples was analyzed as described above.

\section{Density}

The densities of the supernate and precipitate slurry from the solutions beyond $\mathrm{pH} 14$ were determined gravimetrically. A $1 \mathrm{~mL}$ aliquot of the unmixed supernate was transferred to a preweighed 1 dram vial and the mass measured. Then, after stirring the solution, $1 \mathrm{~mL}$ of the 
WSRC-TR-2003-00193

Revision 0

mixture was removed and transferred to a pre-weighed 1 dram vial to determine the density of the mixture.

\section{$\underline{\text { Settling Experiments }}$}

The time required for the solids precipitated in each solution neutralized beyond $\mathrm{pH} 14$ was measured using a $25 \mathrm{~mL}$ graduated cylinder. Prior to the measurement each solution was stirred until well mixed. Nominally $16 \mathrm{~mL}$ of a solution was then transferred to the graduated cylinder. The solids were allowed to settle as time progressed and the volume corresponding to the top of the solids in the graduated cylinder was recorded.

\section{$\underline{\text { Viscosity }}$}

The apparent viscosity of the solutions neutralized beyond $\mathrm{pH} 14$ was determined by measuring the time it took for the solution to transverse through a glass coil (the "racetrack") and using a calibration curve to obtain the viscosity. To establish the calibration curve (Appendix B) for the viscosity experiments, $15 \mathrm{~mL}$ of a series of $\mathrm{NaOH}$ solutions $(0.5-10 \mathrm{M})$ of known viscosity [7] and deionized water were allowed to flow through a standard condenser coil (inner diameter of the tube was $0.6 \mathrm{~cm}$ ) and the corresponding elapsed time was recorded. The time recorded was the interval from the moment the solution began to flow until the first drop left the opening at the bottom of the coil. The viscosity of the neutralized solutions was determined from the calibration curve by measuring the time required for $15 \mathrm{~mL}$ of the (mixed) precipitate slurry to flow through the condenser coil. Each measurement was performed in triplicate and the coil was rinsed with deionized water before initial use and after each set of measurements.

\section{TGA}

The amount of water present in the precipitate was determined by TGA. Samples $(5-25 \mathrm{mg})$ for analysis were removed from each solution neutralized beyond $\mathrm{pH} 14$ after thorough mixing, transferred to a centrifuge tube, and allowed to settle for several days. The samples were then centrifuged ( $5000 \mathrm{~g}$ for five minutes) and the supernate drained. The solids were removed from the sealed tubes just prior to analysis. A $10{ }^{\circ} \mathrm{C} / \mathrm{min}$ linear heating rate was used for the duration of each run (Appendix A). A platinum sample pan was used.

Previous results with calcium oxalate revealed that waters of hydration are typically removed between $150-200{ }^{\circ} \mathrm{C}$ [1]. Using the difference in the weight of the initial sample compared to the weight of the sample at $250^{\circ} \mathrm{C}$ allowed the calculation of hydrogen $(\mathrm{H}): \mathrm{Pu}$ ratios [1].

\section{Results and Discussion}

\section{$\underline{\text { Visual Observations }}$}

Prior to any treatment, the initial Tank 12.1 solution was light yellow-brown in color and transparent with no observable particulate matter. As $\mathrm{NaOH}$ was added, the solution became more orange-brown and solids were briefly observed in solution from $\mathrm{pH} 3.5-4.5$. However, the solids were quickly dissipated due to the continuous stirring. At $\mathrm{pH} 4.5$, the solids remained 
in the beaker and, after the mixed solution was sampled and centrifuged for five minutes, the supernate was light yellow and the precipitate was yellow-orange. The solids were approximately $10 \%$ (by volume) in each vial. When more $\mathrm{NaOH}$ was added to the Tank 12.1 solution to reach $\mathrm{pH} 7$, the amount of solids in the bottom of the centrifuge vials appeared to be greater than at $\mathrm{pH} 4.5$. Following neutralization to either 1.2 or $3.6 \mathrm{M}^{2}$ excess $\mathrm{OH}^{-}$, there was no observable color in the supernate and the precipitate was an orange-brown color. In these experiments, the precipitate appeared to be more densely packed in the bottom of the vials than at $\mathrm{pH} 7$.

After the solution was allowed to stand for one week and the stirring was resumed, the solids were easily dispersed into solution in a manner similar to the previous studies [1].

\section{pH Tests}

With $\mathrm{U}$ present in the 12.1 solution, the most significant difference in the precipitate behavior from the Pu-Gd experiments [1] was the onset of precipitation at $\mathrm{pH} 4.5$ instead of $\mathrm{pH} 3$. The precipitation of solids at the higher $\mathrm{pH}$ is consistent with the behavior of $\mathrm{U}$ solutions. Figure 1 shows the precipitated solutions at the specified $\mathrm{pH}$ values.

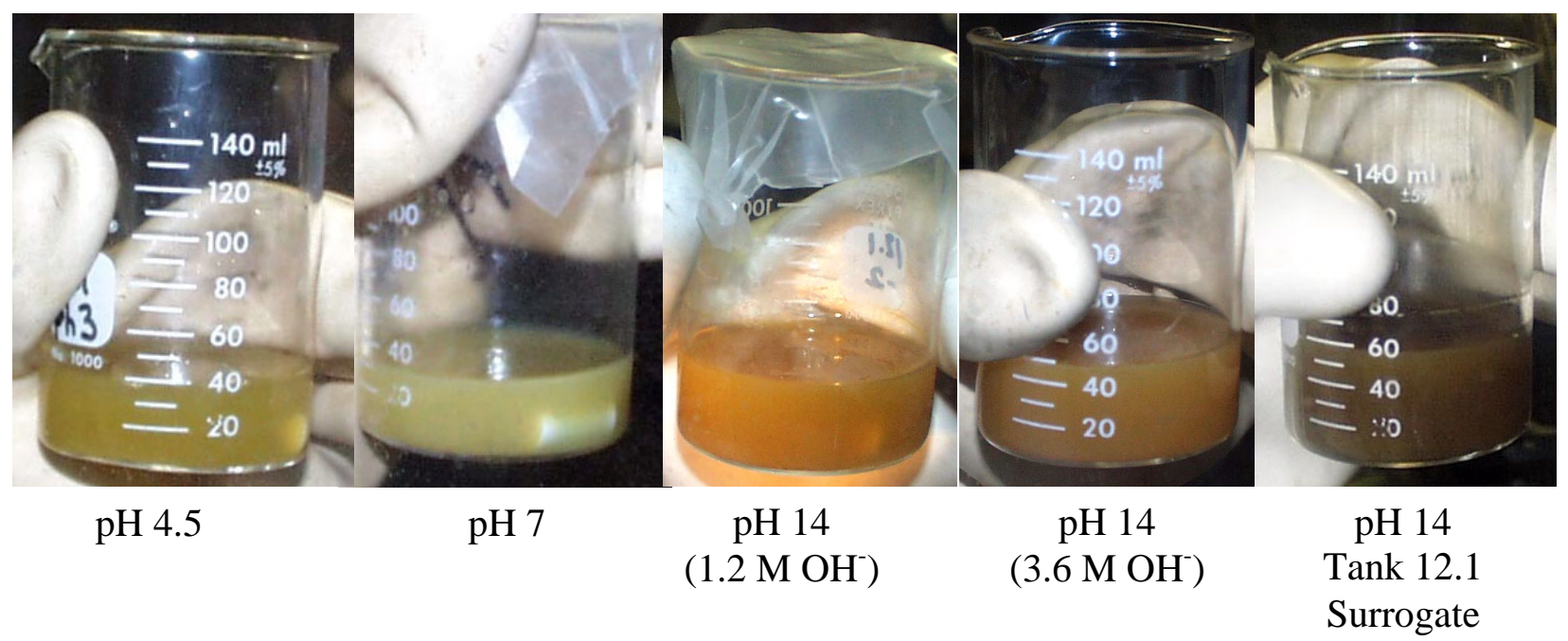

Figure 1: 12.1 Solutions at Specific $\mathrm{pH}$

In comparison to the previous Pu-Gd precipitation studies [1], Table 3 shows the behavior of $\mathrm{U}-\mathrm{Gd}$ and $\mathrm{Pu}-\mathrm{Gd}$ in these experiments. (Appendix A contains examples of calculations for the results presented in Tables 3, 4, and 6).

At $\mathrm{pH} 4.5$, not all the $\mathrm{U}$ and $\mathrm{Gd}$ precipitated. Since much of the $\mathrm{Gd}$ remained in solution while the majority of the $\mathrm{U}$ and $\mathrm{Pu}$ precipitated, the ratios for $\mathrm{U} / \mathrm{Gd}$ and $\mathrm{Pu} / \mathrm{Gd}$ for the solids were significantly greater than one. If, during processing, a mechanical failure would stop the addition of $\mathrm{NaOH}$ before $\mathrm{pH} 7$ is attained, the presence of water (hydrogen is also a neutron poison) would aid in preventing a criticality event. Although only $6 \%$ of the Gd is present in the precipitate at $\mathrm{pH} 4.5$, the ratio of $\mathrm{H}: \mathrm{Gd}: \mathrm{Pu}$ is sufficient to avoid a criticality incident [1]. In the previous studies where the $\mathrm{Gd}: \mathrm{Pu}$ ratios were designed to be 1:1, the precipitate contained 1:20 
$(\mathrm{Gd}: \mathrm{Pu})$ at $\mathrm{pH} 3$ [1]. Here, the presence of $\mathrm{U}$ in solution decreases the ratio to 1:6.1 $(\mathrm{Gd}: \mathrm{Pu})$ at $\mathrm{pH} 4.5$.

Table 3: U/Gd and Pu/Gd Ratios vs. pH of 12.1 Solution

\begin{tabular}{|c|c|c|c|c|}
\hline Sample & $\begin{array}{c}\text { Supernate } \\
\text { U/Gd } \\
(\mathrm{mg} / \mathrm{mg})\end{array}$ & $\begin{array}{c}\text { Solids } \\
\text { U/Gd } \\
(\mathrm{mg} / \mathrm{mg})\end{array}$ & $\begin{array}{c}\text { Supernate } \\
\mathrm{Pu} / \mathrm{Gd} \\
(\mathrm{mg} / \mathrm{mg})\end{array}$ & $\begin{array}{l}\text { Solids } \\
\text { Pu/Gd } \\
\text { (mg/mg) }\end{array}$ \\
\hline $\mathrm{pH} 4.5$ & 0.736 & 13.046 & 0.024 & 6.102 \\
\hline pH 7 & $(0.970)$ & 1.734 & (5.304) & 0.521 \\
\hline pH $14\left(1.2 \mathrm{M} \mathrm{OH}^{-}\right)$ & $(0.974)$ & 1.679 & $(0.890)$ & 0.539 \\
\hline pH $14\left(3.6 \mathrm{M} \mathrm{OH}^{-}\right)$ & (4.283) & 1.723 & 0.371 & 0.520 \\
\hline U Surrogate ( $\left.\mathrm{pH} 14 \& 1.2 \mathrm{M} \mathrm{OH}^{-}\right)$ & $(2.270)$ & 1.847 & na & na \\
\hline Tank 12.1 Surrogate (pH $\left.14 \& 1.2 \mathrm{M} \mathrm{OH}^{-}\right)$ & 3.318 & 2.723 & 0.030 & 1.125 \\
\hline \multicolumn{5}{|l|}{ After One Week } \\
\hline $\mathrm{pH} 4.5$ & 0.674 & 9.078 & 0.012 & 4.612 \\
\hline pH 7 & 17.549 & 1.592 & 0.327 & 0.544 \\
\hline pH $14\left(1.2 \mathrm{M} \mathrm{OH}^{-}\right)$ & $(8.380)$ & 1.727 & 0.628 & 0.513 \\
\hline pH $14\left(3.6 \mathrm{M} \mathrm{OH}^{-}\right)$ & 3.764 & 1.695 & 0.194 & 0.523 \\
\hline U Surrogate ( $\left.\mathrm{pH} 14 \& 1.2 \mathrm{M} \mathrm{OH}^{-}\right)$ & $(9.740)$ & 1.509 & na & na \\
\hline Tank 12.1 Surrogate (pH $\left.14 \& 1.2 \mathrm{M} \mathrm{OH}^{-}\right)$ & 3.318 & 2.729 & 0.066 & 1.435 \\
\hline
\end{tabular}

na $=$ not applicable to sample

Results in parentheses include calculations on data below limit of detection for that element.

Table 4 summarizes the behavior of the elements of interest as a function of $\mathrm{pH}$. At $\mathrm{pH} 4.5$, only $6 \%$ of the Gd precipitated, however, this value is essentially the same as the 5\% measured at $\mathrm{pH}$ 3 in the previous studies [1]. Both $\mathrm{U}$ and $\mathrm{Pu}$ begin to precipitate under these slightly acidic conditions and some boron (B) is also present in the solids. Boron is a nuclear poison and is also used in $\mathrm{H}-$ Canyon to poison some dissolver and $\mathrm{Pu}$ solutions. Its presence is beneficial from a poisoning aspect; however, its presence is not required. At $\mathrm{pH} 7$, at least $95 \%$ of the $\mathrm{Gd}, \mathrm{U}$, and $\mathrm{Pu}$ are removed from solution. Upon complete neutralization $(\mathrm{pH}>14)$, greater than $99 \%$ of these elements were found in the precipitated solids. Based on these results, poisoning the $\mathrm{Pu}-\mathrm{U}$ solutions with $\mathrm{Gd}$ and subsequent neutralization is a viable means for discarding the $\mathrm{Pu}$ to the HLW system.

After one week, analysis of the solids revealed no significant changes in their mass ratios. Thus, short-term storage of the precipitate slurry is possible and the integrity of the solids would be maintained even if left in contact with the aqueous phase.

\section{Density and Settling}

The density (Table 5) of each solution neutralized to greater than $\mathrm{pH} 14$ was measured to characterize the supernate and the supernate/solids mixture. The settling rate of the solids (Table 5 , Figure 2) was also measured to determine how the solution would behave if, during processing or transfer, agitation of the solution was stopped for a period of time. 
WSRC-TR-2003-00193

Revision 0

Table 4: \% (Element in Precipitate/Element in Initial Solution) at each $\mathrm{pH}$

\begin{tabular}{|c|c|c|c|c|}
\hline Initial Sample & $\% \mathrm{Gd}$ & $\% \mathrm{U}$ & $\% \mathrm{Pu}$ & $\% \mathrm{~B}$ \\
\hline $\mathrm{pH} 4.5$ & 6.0 & 53.2 & 94.2 & 9.8 \\
\hline $\mathrm{pH} 7$ & 99.7 & 99.8 & 95.4 & 33.7 \\
\hline pH $14\left(1.2 \mathrm{M} \mathrm{OH}^{-}\right)$ & 99.9 & 99.9 & 99.7 & 7.2 \\
\hline pH $14\left(3.6 \mathrm{M} \mathrm{OH}^{-}\right)$ & 99.5 & 99.8 & 99.8 & 7.0 \\
\hline U Surrogate $\left(\mathrm{pH} 14 \& 1.2 \mathrm{M} \mathrm{OH}^{-}\right)$ & 99.9 & 99.8 & na & na \\
\hline Tank 12.1 Surrogate (pH $\left.14 \& 1.2 \mathrm{M} \mathrm{OH}^{-}\right)$ & 99.9 & 99.9 & 99.9 & na \\
\hline \multicolumn{5}{|l|}{ After One Week } \\
\hline $\mathrm{pH} 4.5$ & 9.8 & 59.6 & 97.8 & 13.9 \\
\hline pH 7 & 99.2 & 91.6 & 99.5 & 37.7 \\
\hline pH $14\left(1.2 \mathrm{M} \mathrm{OH}^{-}\right)$ & 99.9 & 99.9 & 99.5 & 7.3 \\
\hline pH $14\left(3.6 \mathrm{M} \mathrm{OH}^{-}\right)$ & 99.7 & 99.2 & 99.9 & 6.3 \\
\hline U Surrogate $\left(\mathrm{pH} 14 \& 1.2 \mathrm{M} \mathrm{OH}^{-}\right)$ & 99.9 & 99.5 & na & na \\
\hline Tank 12.1 Surrogate (pH $\left.14 \& 1.2 \mathrm{M} \mathrm{OH}^{-}\right)$ & 99.9 & 99.9 & 99.9 & na \\
\hline
\end{tabular}

na $=$ not applicable to this sample

Table 5: Density of pH 14 Solutions

\begin{tabular}{cccc}
\hline \hline Sample & $\begin{array}{c}\text { Density }(\mathrm{g} / \mathrm{mL}) \\
\text { Supernate }\end{array}$ & $\begin{array}{c}\text { Density }(\mathrm{g} / \mathrm{mL}) \\
\text { Supernate and Solids }\end{array}$ & $\begin{array}{c}\text { Settled solids } \\
\text { volume }(\mathrm{mL})^{*}\end{array}$ \\
\hline pH 14 (1.2 $\left.\mathrm{M} \mathrm{OH}^{-}\right)$ & 1.299 & 1.302 & 3.6 \\
pH 14 (3.6 $\left.\mathrm{M} \mathrm{OH}^{-}\right)$ & 1.322 & 1.338 & 3.4 \\
pH 14 U surrogate $\left(1.2 \mathrm{M} \mathrm{OH}^{-}\right)$ & 1.249 & 1.247 & 2.2 \\
Tank 12.1 Surrogate & & & 2.5 \\
$\left(\mathrm{pH} \mathrm{14} \mathrm{\&} \mathrm{1.2} \mathrm{M} \mathrm{OH}^{-}\right)$ & 1.285 & 1.289 &
\end{tabular}

volume of solids in the cylinder, initial mixture volume between $15.9-16.2 \mathrm{~mL}$

The densities of the phases in each system are close to that of $1 \mathrm{M} \mathrm{NaOH}$ and consistent with expected waste densities. Furthermore, the slight differences in the density of the supernate and the solid-supernate mixture suggest that the solids would not immediately settle out of solution and the mixtures could be easily mixed and transferred. In both the $U$ surrogate and the Tank 12.1 surrogate solutions, the absence of $\mathrm{B}$ and other salts decreases the density of both the supernate and the mixed phases.

The density data combined with the results in Figure 2 indicate that the difference in density between the supernate and the solid-supernate mixture have little effect on the settling time for solids formed from the 12.1 solutions at $\mathrm{pHs}$ beyond 14. Despite the miniscule difference in density for the $\mathrm{U}$ surrogate solution phases, the solids settled out of that solution at a relatively rapid rate. It took $\sim 250$ minutes for the solids in both 12.1 solutions to settle to $1 / 4$ of the initial volume. However, it took only 25 minutes for the solids in the $\mathrm{U}$ surrogate solution to settle to $1 / 4$ of the initial volume. As expected, the final volume of the settled solids depends on the amount of total metal ions in solution[8], although certain metal ions (e.g., B) may be especially important. The 12.1 solution contained B and those solutions settled more slowly and resulted in a larger settled solids volume in comparison to both surrogate solutions. 
WSRC-TR-2003-00193

Revision 0

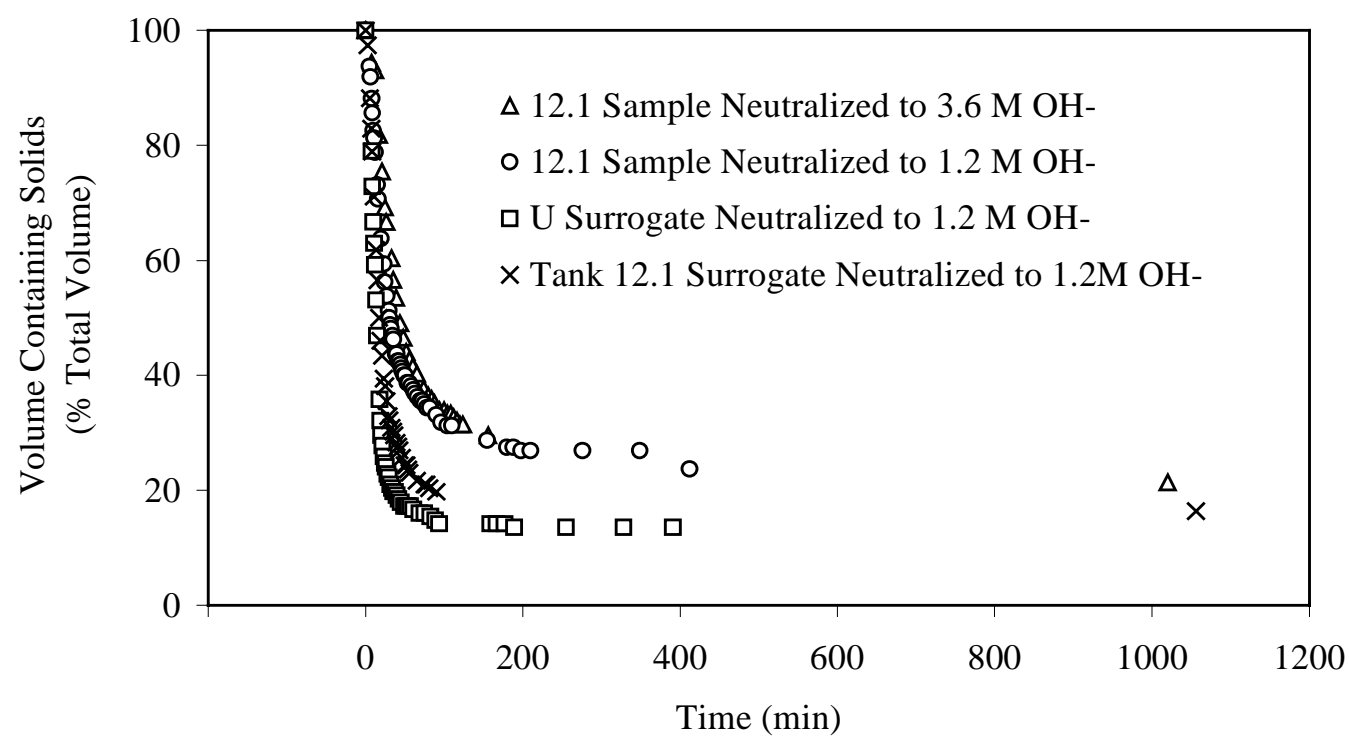

Figure 2: Settling of Solids in $\mathrm{pH} 14$ 12.1 Solutions (1.2 $\mathrm{M} \mathrm{OH}^{-}$and $\left.3.6 \mathrm{M} \mathrm{OH}^{-}\right)$and $\mathrm{pH} 14$ Surrogate Solutions as a Function of Time.

\section{Viscosity}

The viscosity for each $\mathrm{pH} 14$ mixture containing supernate and solids was determined using the calibration curve (Appendix C) developed for the viscosity of $\mathrm{NaOH}$ solutions in the racetrack apparatus. The racetrack consists of the spiral glass tubing removed from the inside of a standard laboratory condenser. The solution is poured into the top of the coil and the elapsed time before the solution exits the bottom of the $28 \mathrm{~cm}$ long coil is related to the viscosity. The results are summarized in Table 6.

Table 6: Viscosity (cP) for $\mathrm{pH} 14$ Tank 12.1 and Surrogate Solutions

\begin{tabular}{cc}
\hline & $\begin{array}{c}\text { Calculated Viscosity } \\
\text { Sample }\end{array}$ \\
\hline $\mathrm{pH} \mathrm{14}\left(1.2 \mathrm{M} \mathrm{OH}^{-}\right)$ & 3.12 \\
$\mathrm{pH} 14\left(3.6 \mathrm{M} \mathrm{OH}^{-}\right)$ & 4.54 \\
U Surrogate $\left(\mathrm{pH} 14 \& 1.2 \mathrm{M} \mathrm{OH}^{-}\right)$ & 2.43 \\
Tank 12.1 Surrogate $\left(\mathrm{pH} 14 \& 1.2 \mathrm{M} \mathrm{OH}^{-}\right)$ & 2.21 \\
\hline
\end{tabular}

In each case, the presence of a significant amount of solids in the solution did not obstruct the flow of the mixture through the $0.6 \mathrm{~cm}$ inner diameter coil. (After each run, some solution was retained along the bottom of each turn throughout the length of the condenser, but this residual amount was no problem for smooth flow as each solution was run in triplicate.) The increase in the salt concentration from $1.2 \mathrm{M} \mathrm{OH}^{-}$to $3.6 \mathrm{M} \mathrm{OH}^{-}$resulted in an expected increase in the viscosity, although the effect was small. For comparison, the viscosities of both 12.1 solutions and both surrogate solutions are similar to that of $4-6 \mathrm{M} \mathrm{NaOH}$ solutions [7].

$\underline{\text { SEM and XRD }}$ 
WSRC-TR-2003-00193

Revision 0

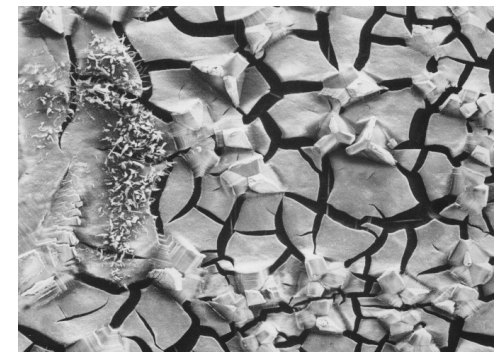

SEM pH 4.5 (500X)

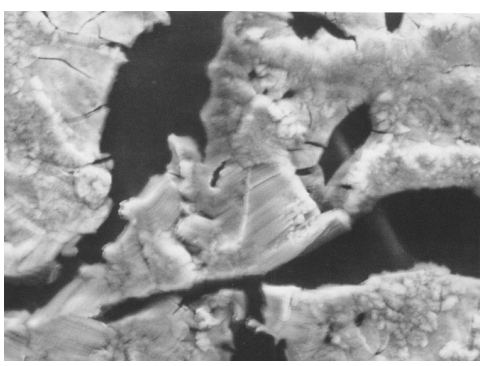

SEM pH 7 (50X)

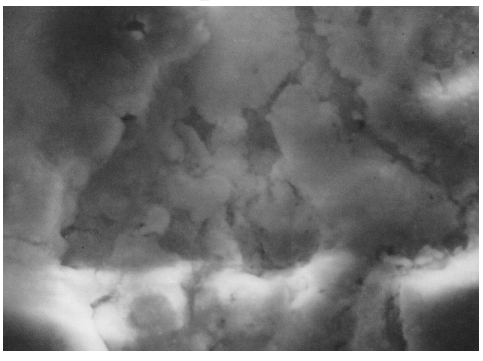

SEM pH 14, 3.6 M (1000X)

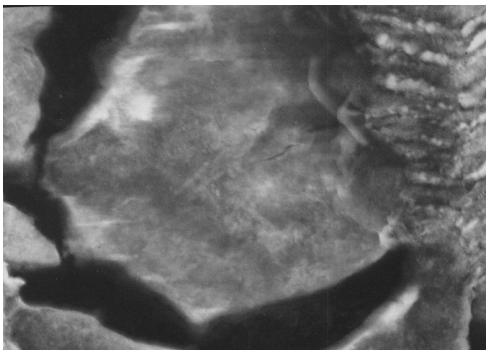

SEM pH 14, 1.2 M (500X)

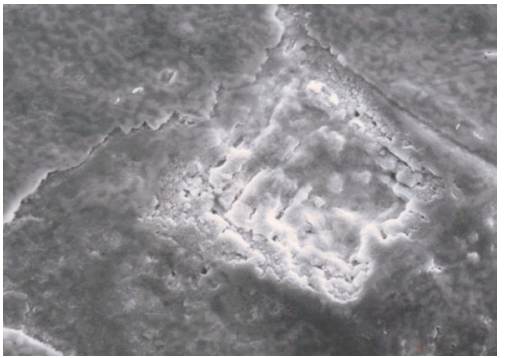

SEM Tk. 12.1 Surr. (500X)

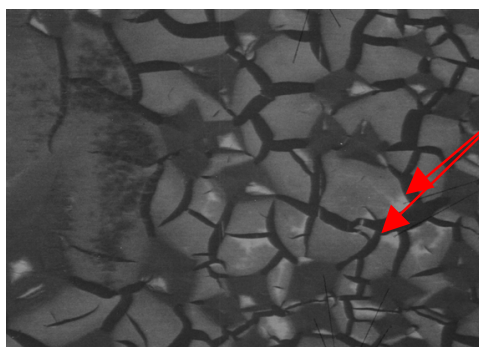

BSE pH 4.5 (500X)

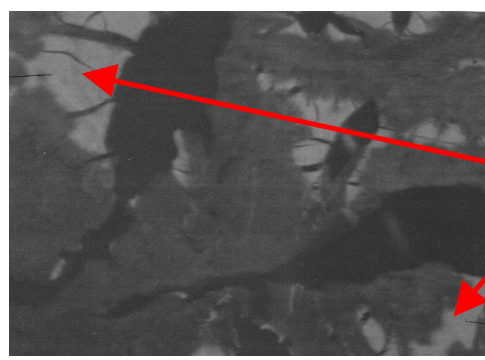

BSE pH 7 (50X)

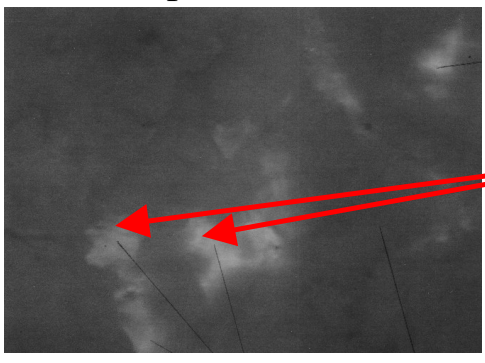

BSE pH 14, 3.6 M (1000X)

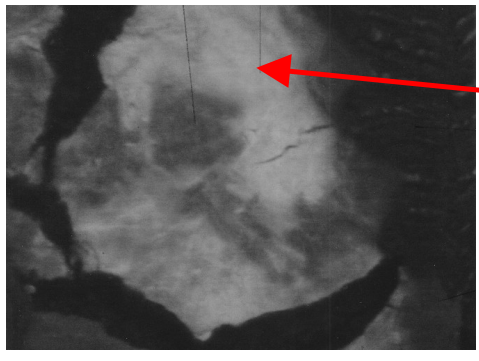

BSE pH 14, 1.2 M (500X)

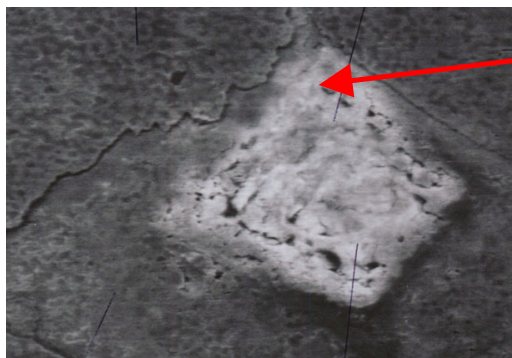

BSE Tk 12.1 Surr. (500X)

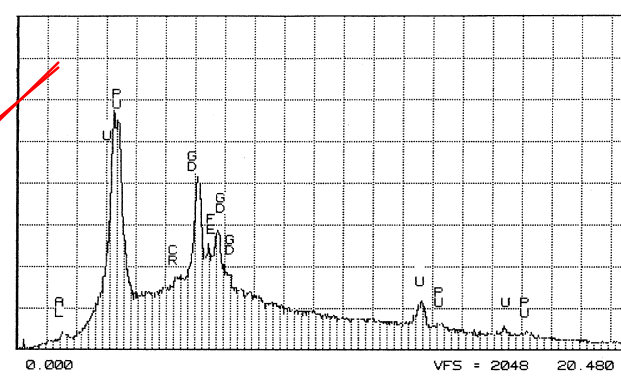

EDS pH 4.5

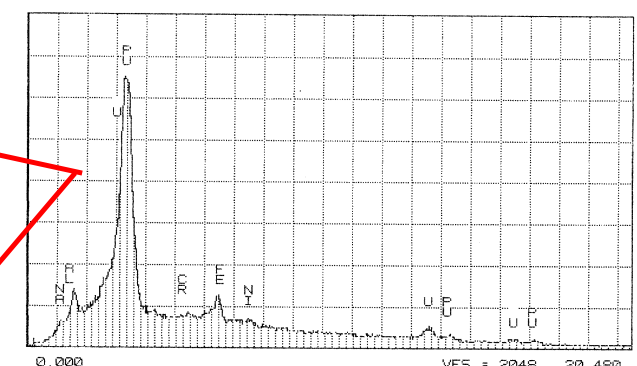

EDS pH 7

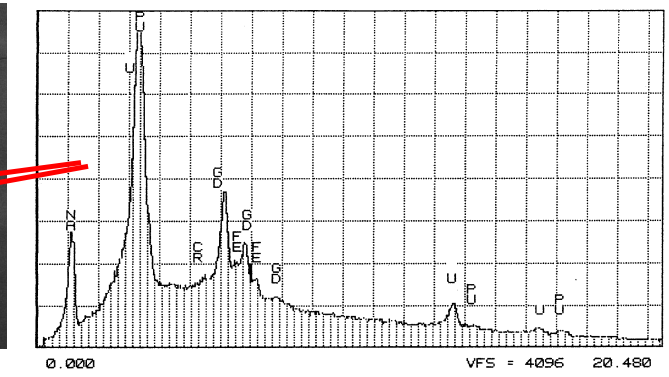

EDS pH 14, 3.6 $\mathrm{M} \mathrm{OH}^{-}$

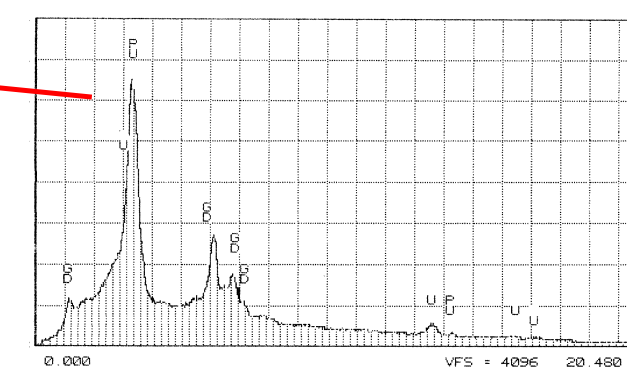

EDS pH 14, 1.2 $\mathrm{M} \mathrm{OH}^{-}$

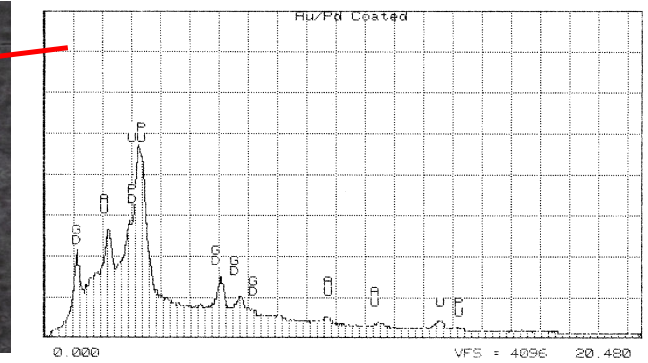

EDS Tk. 12.1 Surr.

Figure 3: SEM, BSE, and EDS of precipitates from solutions adjusted to the specified $\mathrm{pH}$ 
Figure 3 shows SEM, back-scattering electron analysis (BSE), and an energy dispersive spectrum (EDS) for a selected spot for solids from each sample. XRD analyses of the solids obtained from these precipitation experiments reveal a variety of solids. At $\mathrm{pH} 4.5$, the solids are amorphous with crystalline sodium nitrate $\left(\mathrm{NaNO}_{3}\right)$ on top.

The EDS have broad areas of Pu-U-Gd and U-Gd, but no specific Pu particles. This analysis agrees with the results from the XRD analysis for the initial samples where few crystal structures were found, which would occur in samples containing amorphous solids or $<10 \mu \mathrm{m}$ crystals. Samples that sat longer (one week) did have a composition similar to the results from the previous studies (e.g., plutonium and gadolinium oxides $\left(\mathrm{PuO}_{2}\right.$ and $\left.\mathrm{Gd}_{2} \mathrm{O}_{3}\right)$ ) [1]. At $\mathrm{pH} 4.5$, the solids contained an abundance of $\mathrm{Pu}$ and $\mathrm{U}$ with small amounts of iron (Fe). At pH 7 and $\mathrm{pH} 14$ (for both 1.2 and $3.6 \mathrm{M}$ excess $\mathrm{OH}^{-}$), $\mathrm{Pu}, \mathrm{U}, \mathrm{Fe}$, and $\mathrm{Gd}$ were all detected in the solids.

Analysis of the XRD results revealed that at 3.6 M excess $\mathrm{OH}^{-}, \mathrm{U}$ was present in the solids in the form of sodium diuranate $\left(\mathrm{Na}_{2} \mathrm{U}_{2} \mathrm{O}_{7}\right)$. After one week, uranium dioxide $\left(\mathrm{UO}_{2}\right)$ and clarkeite $\left(\mathrm{Na}\left[\left(\mathrm{UO}_{2}\right) \mathrm{O}\right](\mathrm{OH}) \cdot \mathrm{H}_{2} \mathrm{O}\right)$ were also found in the solids. Clarkeite was present at $\mathrm{pH} 4.5$. In addition to clarkeite, $\mathrm{NaNO}_{3}$, sodium carbonate $\left(\mathrm{Na}_{2} \mathrm{CO}_{3}\right)$, and $\mathrm{Gd}(\mathrm{OH})_{3}$ were detected in the solids obtained from the $\mathrm{U}$ surrogate solution. No crystalline compounds containing $\mathrm{Pu}$ or $\mathrm{Gd}$ were detected by XRD in any precipitate obtained from 12.1 solutions. In the previous studies [1], an amorphous material was produced, likely due to the formation of hydroxides. The x-ray diffraction pattern from the amorphous material after it was heated could be fit to $\mathrm{PuO}_{2}$ and $\mathrm{Gd}_{2} \mathrm{O}_{3}$, although the $\mathrm{Pu}$ and $\mathrm{Gd}$ were so closely associated that the $\mathrm{x}$-ray patterns could not be uniquely assigned.

\section{$\underline{\text { TGA }}$}

The solutions neutralized to pHs beyond 14 were analyzed by TGA to determine the number of water molecules associated with the solids and, ultimately, the ratio of hydrogen $(\mathrm{H})$ atoms to $\mathrm{Pu}$ atoms. Bronikowski et al., performed similar analyses although the samples were prepared in a different manner by evaporating and heating the sample [1]. The resulting H:Pu ratio was 150:1. The minimum H:Pu ratio, as determined by the Nuclear Criticality Safety Evaluation for use of Gd as a neutron poison at a 1:1 weight ratio was 30 .

The Tank 12.1 samples neutralized to 1.2 or $3.6 \mathrm{M}$ excess $\mathrm{OH}^{-}$had $\mathrm{H}: \mathrm{Pu}$ ratios of $483: 1$ and 343:1, respectively. Part of this difference could be attributed to differences in sample preparation and precipitate composition. Thus, the $\mathrm{H}: \mathrm{Pu}$ ratios here are 3 to 4 times greater in comparison to the previous results.

\section{Conclusions}

Small-scale precipitation experiments were performed to assess the behavior of $\mathrm{Pu}-\mathrm{U}-\mathrm{Gd}$ solutions from H-Canyon Tanks 12.1 and 16.3 during caustic neutralization. These experiments confirmed that $\mathrm{Gd}$ is a viable poison for dispositioning these solutions to the SRS HLW system. The presence of three times more $U$ than Pu caused a sample of the 12.1 solution to precipitate at $\mathrm{pH} 4.5$ which is consistent with the behavior of uranium solutions. At this $\mathrm{pH}, 6 \%$ of the $\mathrm{Gd}$ was found in the precipitate solids. This value is essentially the same as the $5 \%$ measured at $\mathrm{pH} 3$ in 
previous studies on $\mathrm{Pu}-\mathrm{Gd}$ solutions. At $\mathrm{pH} 7$, at least $95 \%$ of the $\mathrm{Gd}, \mathrm{U}$, and $\mathrm{Pu}$ were removed from solution. Upon complete neutralization (to 1.2 and $3.6 \mathrm{M}$ excess $\mathrm{OH}^{-}$), greater than $99 \%$ of these elements was found in the precipitated solids.

Thermal gravimetric analysis of centrifuged solids indicated the ratio of $\mathrm{H}$ (from water) to $\mathrm{Pu}$ was 343:1 following neutralization to $3.6 \mathrm{M}$ excess $\mathrm{OH}^{-}$and 483:1 following neutralization to 1.2 $\mathrm{M}$ excess $\mathrm{OH}^{-}$. These values greatly exceed the minimum $\mathrm{H}: \mathrm{Pu}$ ratio of 30:1 required for the use of $\mathrm{Gd}$ as a neutron poison. Rheological properties of the precipitate slurry were also evaluated following neutralization. After one week without agitation, the precipitate solids were easily re-suspended in the supernate and settled to approximately $25 \%$ of the total volume in approximately 250 minutes. The apparent viscosity of the neutralized solution was equivalent to 4-6M NaOH; therefore, no problems in transferring the precipitate slurry are anticipated. 


\section{References}

1. M. G. Bronikowski, J. H. Gray, B. C. Hill, F. R. Graham, D. G. Karraker, Caustic Precipitation of Plutonium Using Gadolinium as the Neutron Poison for Disposition to High Level Waste, Report No. WSRC-TR-2002-00198, Aiken, SC (May 3, 2002)

2. H. G. Riella, M. Durazzo, M. Hirata, and R. A. Noguiera, " $\mathrm{UO}_{2}-\mathrm{Gd}_{2} \mathrm{O}_{3}$ Solid Solution Formation From Wet and Dry Processes," J. Nucl. Mater. 178, 1991, 204-211.

3. P. V. Ravindran, K. V. Rajagopalan, and P. K. Mathur, "A Feasibility Study of the Preparation of $(\mathrm{U}, \mathrm{Gd})_{3} \mathrm{O}_{8}$ Solid Solutions by Thermal Decomposition of Co-precipitated Carbonate Mixtures," J. Nucl. Mater. 257, 1998, 189-193.

4. R. C. Lloyd, E. D. Clayton, and L. E. Hansen, "Criticality of Plutonium Nitrate Solution Containing Soluble Gadolinium," Nucl. Sci. Eng. 48, 1972, 300-304.

5. C. F. Baes Jr. and R. E. Mesmer, Hydrolysis of Cations, Wiley-Interscience: New York, 1976.

6. M. G. Bronikowski, M. L. Crowder, and M. C. Thompson, Technical Basis for Safe Operations with Pu-239 Polymer in NMS\&S Operating Facilities (F\&H Areas), Report No. WSRC-TR-99-00008, Aiken, SC (January 1999).

7. CRC Handbook of Chemistry and Physics, D. R. Lide (Ed.), $83^{\text {rd }}$ edition, 2003.

8. D. T. Hobbs, "Precipitation of Uranium and Plutonium From Alkaline Salt Solution," Nucl. Technol. 128, 1999, 103-112. 


\section{$\underline{\text { Appendix A }}$}

\section{Example Calculations:}

\section{$\underline{\text { In general }}$}

For each calculation, the results from the ICP-ES analyses were multiplied by 10 to account for the 1:9 dilution incorporated during sample preparation. The TTA extraction and gamma scan results were not multiplied by 10 since no dilution was made while preparing those samples. If the amount of the element of interest was below detection limits for ICP-ES (e.g., $<2.27 \mathrm{mg} / \mathrm{L}$ ), the sample was considered to contain $2.27 \mathrm{mg} / \mathrm{L}$. The concentration was then multiplied by 10 . In Table 3, numbers in parentheses indicate where these considerations have been applied.

\section{Conversion of Pu TTA Extraction Data}

The $\mathrm{Pu}$ results from TTA extraction were reported in $\mathrm{dpm} / \mathrm{mL}$ and were converted to their specific activity and then $\mathrm{g} / \mathrm{mL}$. The isotopic composition of $\mathrm{Pu}$ in the 12.1 solution was reported to be $88 \%{ }^{239} \mathrm{Pu}$ and $12 \%{ }^{240} \mathrm{Pu}$. The TTA extraction results are reported as the sum of both ${ }^{239} \mathrm{Pu}$ and ${ }^{240} \mathrm{Pu} \mathrm{dpm} / \mathrm{mL}$ while ${ }^{238} \mathrm{Pu}$ is separate.

To obtain the specific activity for each Pu isotope (238, 239, and 240), the following equation was used:

$$
\text { Specific activity of } \mathrm{Pu}(\mathrm{Ci} / \mathrm{g})=3.578 \times 10^{5} /\left[\left(\mathrm{t}_{1 / 2}(\mathrm{yr})\right) *(\text { atomic mass for that isotope })\right]
$$

The specific activity $(\mathrm{Ci} / \mathrm{g})$ was then multiplied by the conversion factor $2.22 \times 10^{12} \mathrm{dpm} / \mathrm{Ci}$ to obtain specific activity in units of $\mathrm{dpm} / \mathrm{g}$ for that isotope.

The specific activity for each $\mathrm{Pu}$ isotope is:

$$
\begin{aligned}
& { }^{238} \mathrm{Pu} \text { specific activity }=\left[3.578 \times 10^{5} /(87.7 * 238)\right] \times 2.22 \times 10^{12}=3.806 \times 10^{13} \mathrm{dpm} / \mathrm{g} \\
& { }^{239} \mathrm{Pu} \text { specific activity }=\left[3.578 \times 10^{5} /\left(24110^{*} 239\right)\right] \times 2.22 \times 10^{12}=1.378 \times 10^{11} \mathrm{dpm} / \mathrm{g} \\
& \mathrm{Pu} \text { specific activity }=\left[3.578 \times 10^{5} /(6564 * 240)\right] \times 2.22 \times 10^{12}=5.042 \times 10^{11} \mathrm{dpm} / \mathrm{g}
\end{aligned}
$$

Considering the isotopic distribution, the specific activity of ${ }^{239+240} \mathrm{Pu}$ in the $12.1+$ Gd solution is then:

$$
\text { Eq. } 1 \quad(0.88)\left(1.378 \times 10^{11} \mathrm{dpm} / \mathrm{g}\right)+(0.12)\left(5.042 \times 10^{11} \mathrm{dpm} / \mathrm{g}\right)=1.818 \times 10^{11} \mathrm{dpm} / \mathrm{g}
$$

In the initial $12.1+\mathrm{Gd}$ solution, total ${ }^{239+240} \mathrm{Pu}$ is $1.99 \times 10^{8} \mathrm{dpm} / \mathrm{mL}$ (from TTA extraction analysis). To convert the $\mathrm{dpm} / \mathrm{mL}$ from the TTA extraction to $\mathrm{mg} / \mathrm{L}$, divide by the sum of the specific activities for ${ }^{239} \mathrm{Pu}$ and ${ }^{240} \mathrm{Pu}$ as calculated from Eq. 1 above.

Eq. 2

$$
\left(1.99 \times 10^{8} \mathrm{dpm} / \mathrm{mL}\right) /\left(1.818 \times 10^{11} \mathrm{dpm} / \mathrm{g}\right) * 1 \times 10^{6}=1094.6 \mathrm{mg} / \mathrm{L}
$$

The raw TTA extraction data is summarized in Table A.1. 
WSRC-TR-2003-00193

Revision 0

Table A.1: Results from TTA Extraction

\begin{tabular}{|c|c|c|}
\hline Sample & ${ }^{239+240} \mathrm{Pu}(\mathrm{dpm} / \mathrm{mL})$ & ${ }^{239+240} \mathrm{Pu}(\mathrm{mg} / \mathrm{L})$ \\
\hline \multicolumn{3}{|l|}{ Initial Sampling } \\
\hline $12.1+$ Gd Initial & $1.99 \times 10^{8}$ & 1094.6 \\
\hline 1pH3a Solids & $1.42 \times 10^{8}$ & 781.1 \\
\hline 1pH3b Supernate & $5.82 \times 10^{6}$ & 32.0 \\
\hline 1pH7a Solids & $6.97 \times 10^{7}$ & 383.4 \\
\hline 1pH7b Supernate & $2.22 \times 10^{6}$ & 12.2 \\
\hline 1pH14a $\left(3.6 \mathrm{M} \mathrm{OH}^{-}\right)$Solids & $1.74 \times 10^{8}$ & 957.1 \\
\hline $1 \mathrm{pH} 14 \mathrm{~b}\left(3.6 \mathrm{M} \mathrm{OH}^{-}\right)$Supernate & $3.43 \times 10^{5}$ & 1.9 \\
\hline $1 \mathrm{pH} 14 \mathrm{a}-2\left(1.2 \mathrm{M} \mathrm{OH}^{-}\right)$Solids & $1.52 \times 10^{8}$ & 836.1 \\
\hline $1 \mathrm{pH} 14 \mathrm{~b}-2\left(1.2 \mathrm{M} \mathrm{OH}^{-}\right)$Supernate & $1.63 \times 10^{5}$ & 0.89 \\
\hline 1pH14a Tank Surrogate Solids & $1.43 \times 10^{8}$ & 1550 \\
\hline 1pH14b Tank Surrogate Supernate & $2.21 \times 10^{4}$ & 0.15 \\
\hline Initial Tank Surrogate & $1.63 \times 10^{8}$ & 1020 \\
\hline \multicolumn{3}{|l|}{ Sampling after 1 week } \\
\hline 2pH3a Solids & $1.82 \times 10^{8}$ & 1001.1 \\
\hline 2pH3b Supernate & $2.77 \times 10^{6}$ & 15.23 \\
\hline 2pH7a Solids & $1.82 \times 10^{8}$ & 1001.1 \\
\hline 2pH7b Supernate & $5.84 \times 10^{5}$ & 3.21 \\
\hline 2pH14a $\left(3.6 \mathrm{M} \mathrm{OH}^{-}\right)$Solids & $1.56 \times 10^{8}$ & 858.8 \\
\hline $2 \mathrm{pH} 14 \mathrm{~b}\left(3.6 \mathrm{M} \mathrm{OH}^{-}\right)$Supernate & $5.72 \times 10^{5}$ & 3.14 \\
\hline 2pH14a-2 (1.2M OH') Solids & $1.81 \times 10^{8}$ & 995.5 \\
\hline $2 \mathrm{pH} 14 \mathrm{~b}-2\left(1.2 \mathrm{M} \mathrm{OH}^{-}\right)$Supernate & $9.63 \times 10^{4}$ & 0.52 \\
\hline 2pH14a Tank Surrogate Solids & $2.49 \times 10^{8}$ & 1550 \\
\hline 2pH14b Tank Surrogate Supernate & $2.46 \times 10^{4}$ & 0.15 \\
\hline
\end{tabular}

Representative calculation for the results in Table 3.

To determine the U:Gd ratio, the ICP-ES results for $\mathrm{U}$ were divided by those for Gd. For example, at $\mathrm{pH} 4.5$ :

$1670 \mathrm{mg} / \mathrm{L} \mathrm{U}$ in solids from ICP-ES

$128 \mathrm{mg} / \mathrm{L} \mathrm{Gd}$ in solids from ICP-ES

Thus, the U:Gd ratio is $1670 / 128=13.046$

To determine the Pu:Gd ratio, the TTA extraction results for $\mathrm{Pu}$ in $\mathrm{dpm} / \mathrm{mL}$ were converted into $\mathrm{mg} / \mathrm{L}$ as shown above in Eq. 2.

Then, the Pu:Gd ratio was determined by dividing the TTA extraction results for Pu by the ICPES results for Gd. For example, at $\mathrm{pH}$ 4.5: 
$781 \mathrm{mg} / \mathrm{L} \mathrm{Pu}$ in solids from TTA extraction $128 \mathrm{mg} / \mathrm{L} \mathrm{Gd}$ in solids from ICP-ES

Thus, the Pu:Gd ratio is $781 / 128=6.101$

The ICP-ES results are summarized in Table A.2.

Table A.2: Results from ICP-ES

\begin{tabular}{|c|c|c|c|}
\hline Sample & $\mathrm{B}(\mathrm{mg} / \mathrm{L})$ & $\mathrm{Gd}(\mathrm{mg} / \mathrm{L})$ & $\mathrm{U}(\mathrm{mg} / \mathrm{L})$ \\
\hline \multicolumn{4}{|l|}{ Initial Sampling } \\
\hline $12.1+$ Gd Initial & 2910 & 1750 & 3000 \\
\hline 1pH3a Solids & 331 & 128 & 1670 \\
\hline 1pH3b Supernate & 2010 & 1330 & 979 \\
\hline 1pH7a Solids & 1090 & 1620 & 2810 \\
\hline 1pH7b Supernate & 1430 & $2.3^{*}$ & $22.7^{*}$ \\
\hline 1pH14a (3.6 $\left.\mathrm{M} \mathrm{OH}^{-}\right)$Solids & 200 & 1550 & 2670 \\
\hline 1pH14b (3.6 $\left.\mathrm{M} \mathrm{OH}^{-}\right)$Supernate & 1770 & 5.3 & $22.7^{*}$ \\
\hline $1 \mathrm{pH} 14 \mathrm{a}-2$ (1.2M OH $\left.\mathrm{OH}^{-}\right)$Solids & 236 & 1840 & 3090 \\
\hline $1 \mathrm{pH} 14 \mathrm{~b}-2\left(1.2 \mathrm{M} \mathrm{OH}^{-}\right)$Supernate & 2010 & $1.0^{*}$ & $9.7^{*}$ \\
\hline Initial U/Gd Surrogate Solution & 7.2 & 1920 & 3010 \\
\hline 1Ua Solids & 16.8 & 2080 & 3400 \\
\hline 1Ub Supernate & 36.9 & $2.3^{*}$ & $22.7^{*}$ \\
\hline Initial $\mathrm{Pu} / \mathrm{U} / \mathrm{Gd}$ Tank Surrogate & 2.7 & 968 & 2650 \\
\hline 1pH14a Tank Surrogate Solids & na & 795 & 2170 \\
\hline 1pH14b Tank Surrogate Surrogate & na & 6.78 & 22.5 \\
\hline \multicolumn{4}{|l|}{ Sampling after 1 week } \\
\hline 2pH3a Solids & 484 & 217 & 1970 \\
\hline 2pH3b Supernate & 3000 & 1320 & 890 \\
\hline 2pH7a Solids & 1260 & 1840 & 2930 \\
\hline 2pH7b Supernate & 1390 & 10.2 & 179 \\
\hline 2pH14a (3.6 $\left.\mathrm{M} \mathrm{OH}^{-}\right)$Solids & 178 & 1640 & 2780 \\
\hline 2pH14b (3.6 $\left.\mathrm{M} \mathrm{OH}^{-}\right)$Supernate & 1760 & 3.5 & 13.1 \\
\hline $2 \mathrm{pH} 14 \mathrm{a}-2\left(1.2 \mathrm{M} \mathrm{OH}^{-}\right)$Solids & 258 & 1940 & 3350 \\
\hline $2 \mathrm{pH} 14 \mathrm{~b}-2\left(1.2 \mathrm{M} \mathrm{OH}^{-}\right)$Supernate & 2040 & 5.3 & $44.5^{*}$ \\
\hline 2Ua Solids & 19.1 & 2080 & 3140 \\
\hline 2Ub Supernate & 45.2 & $0.1^{*}$ & $1.0^{*}$ \\
\hline 2pH14a Tank Surrogate Solids & 50.1 & 1080 & 2940 \\
\hline 2pH14b Tank Surrogate Supernate & 107 & $2.4^{*}$ & $22.7^{*}$ \\
\hline
\end{tabular}

"Data that was below limit of detection but has been multiplied by 10. 
Representative calculation for the results in Table 4.

For example, at $\mathrm{pH} 4.5$, ICP-ES results for the sample at $\mathrm{pH} 4.5$ reveal the following concentrations:

$128 \mathrm{mg} / \mathrm{L} \mathrm{Gd}$ in solids

$1330 \mathrm{mg} / \mathrm{L} \mathrm{Gd}$ in supernate

Since $1.5 \mathrm{~mL}$ of the stirred solution was transferred to the centrifuge vial, the amount of Gd in the supernate was multiplied by $0.0015 \mathrm{~L}$. Thus, $1330 \mathrm{mg} / \mathrm{L} * 0.0015 \mathrm{~L}=1.995 \mathrm{mg}$.

To determine the percentage of $\mathrm{Gd}$ in the precipitate, the mass of the element of interest in the solids was multiplied by $0.001 \mathrm{~L}$. The result was then divided by the sum of the masses of the element of interest in both the supernate and the solids. For example, $\% \mathrm{Gd}$ precipitated at $\mathrm{pH}$ 4.5:

$[(128 \mathrm{mg} / \mathrm{L} * 0.001 \mathrm{~L}) /((1330 \mathrm{mg} / \mathrm{L} * 0.0015 \mathrm{~L})+(128 \mathrm{mg} / \mathrm{L} * 0.001 \mathrm{~L})) \times 100=6.029 \%$

This method was used to determine the amount of $\mathrm{B}, \mathrm{Gd}, \mathrm{Pu}$, and $\mathrm{U}$ in the precipitate for both initial and 1-week solutions.

\section{$\underline{\text { Representative Calculation for } \mathrm{Pu}: \mathrm{H} \text { from TGA }}$}

Bronikowski et al. [1] indicates that the expected temperature range for water of hydration loss is between $150-200{ }^{\circ} \mathrm{C}$ for these types of samples. The previous report used the weight loss of the initial solid to that at $250{ }^{\circ} \mathrm{C}$ as the amount of water lost. The same consideration was applied to these calculations.

The following calculations were done with the $\mathrm{pH} 141.2 \mathrm{M} \mathrm{OH}^{-}$sample.

Initial sample weight $=29.09 \mathrm{mg}$

Sample weight at $250{ }^{\circ} \mathrm{C}=12.1 \mathrm{mg}$

$$
\text { Water lost }=16.9 \mathrm{mg}
$$

From ICP-ES and TTA extraction solids results, in $1 \mathrm{~mL}$ there is $3.090 \mathrm{mg} \mathrm{U}, 0.836 \mathrm{mg} \mathrm{Pu}$, and $1.840 \mathrm{mg} \mathrm{Gd}$. Relative to $\mathrm{Pu}$, weight ratios are 3.7:1 U:Pu and 2.2:1 for $\mathrm{Gd}: \mathrm{Pu}$.

Number of moles is as follows:

U $\quad 3.090 \mathrm{mg} /(1000 \mathrm{mg} / \mathrm{g} * 238 \mathrm{~g} / \mathrm{mole})=1.29 \times 10^{-5}$ moles

Moles vs. moles of $\mathrm{Pu}$

Gd $\quad 1.840 \mathrm{mg} /(1000 \mathrm{mg} / \mathrm{g} * 157 \mathrm{~g} / \mathrm{mole})=1.17 \times 10^{-5} \mathrm{moles}$

$\mathrm{Pu} \quad 0.836 \mathrm{mg} /(1000 \mathrm{mg} / \mathrm{g} * 239 \mathrm{~g} / \mathrm{mole})=3.49 \times 10^{-6}$ moles 
At $\mathrm{pH} 14$, the precipitate is composed of $\mathrm{Gd}(\mathrm{OH})_{3}, \mathrm{Pu}(\mathrm{OH})_{4}$, and $\mathrm{Na}_{2} \mathrm{U}_{2} \mathrm{O}_{7}$. Using the weight ratios, the average molecular weight for the precipitate (assuming the precipitate is only $\mathrm{Gd}(\mathrm{OH})_{3}, \mathrm{Pu}(\mathrm{OH})_{4}$, and $\left.\mathrm{Na}_{2} \mathrm{U}_{2} \mathrm{O}_{7}\right)$ is calculated as follows:

$\left(3.69\right.$ moles $\left.^{*} 634 \mathrm{~g} / \mathrm{mole} \mathrm{Na}_{2} \mathrm{U}_{2} \mathrm{O}_{7}\right)+\left(3.35\right.$ moles $\left.^{*} 208 \mathrm{~g} / \mathrm{mole} \mathrm{Gd}(\mathrm{OH})_{3}\right)+\left(307 \mathrm{~g} / \mathrm{mole} \mathrm{Pu}(\mathrm{OH})_{4}\right)=$ 3108 grams $/(3.69$ moles +3.35 moles +1 mole $)=385.6 \mathrm{~g} / \mathrm{mole}$

$0.0121 \mathrm{~g}$ of sample left in TGA pan $\mathrm{x}(1 \mathrm{~mole} / 385.6 \mathrm{~g})=3.14 \times 10^{-5}$ moles (average)

Moles of $\mathrm{Pu}: 3.14 \times 10^{-5}$ moles $/ 8.06=3.907 \times 10^{-6}$ moles $\mathrm{Pu}$

Moles of Gd: $3.907 \times 10^{-6}$ moles Pu x $(3.35$ moles Gd/1 mole Pu $)=1.309 \times 10^{-5}$ moles Gd

Moles of $\mathrm{H}_{2} \mathrm{O}: \quad 0.0169 \mathrm{~g} /(18 \mathrm{~g} / \mathrm{mole})=9.43 \times 10^{-4}$ moles $\mathrm{H}_{2} \mathrm{O}$

Ratio: $9.43 \times 10^{-4}$ moles water/3.907 $\times 10^{-6}$ moles $\mathrm{Pu}=241.6$ moles $\mathrm{H}_{2} \mathrm{O}, 483$ moles $\mathrm{H}: 1 \mathrm{~mole} \mathrm{Pu}$.

Calculation does not take into account the hydrogen atoms associated with $\mathrm{Pu}(\mathrm{OH})_{4}$ and $\mathrm{Gd}(\mathrm{OH})_{3}$; therefore, it is conservative. 
$\underline{\text { Appendix B }}$

TGA of Solids at $\mathrm{pH} 14$

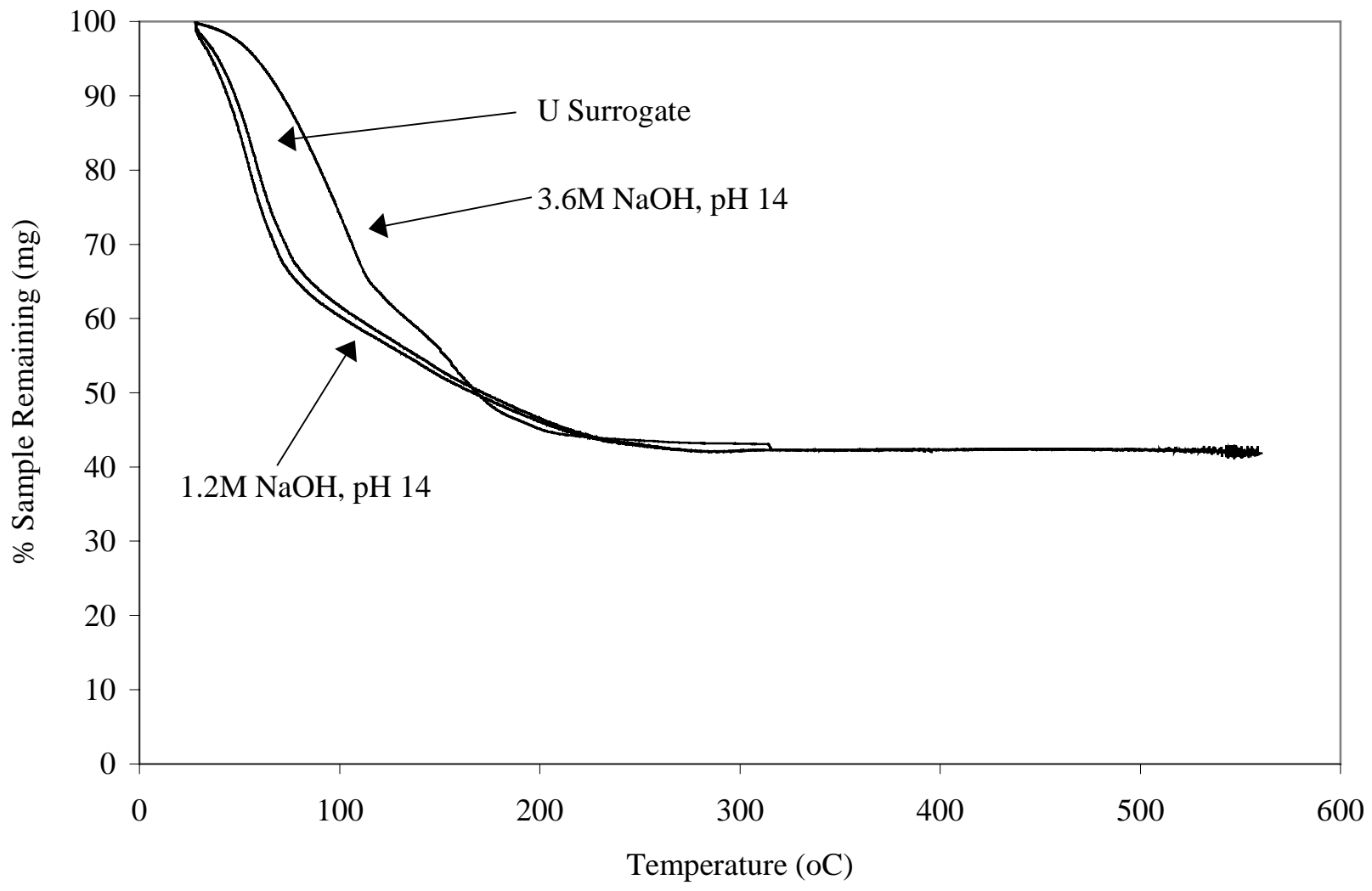

Figure B.1: TGA of pH 14 solids. 


\section{$\underline{\text { Appendix C }}$}

Calibration to Determine Viscosity

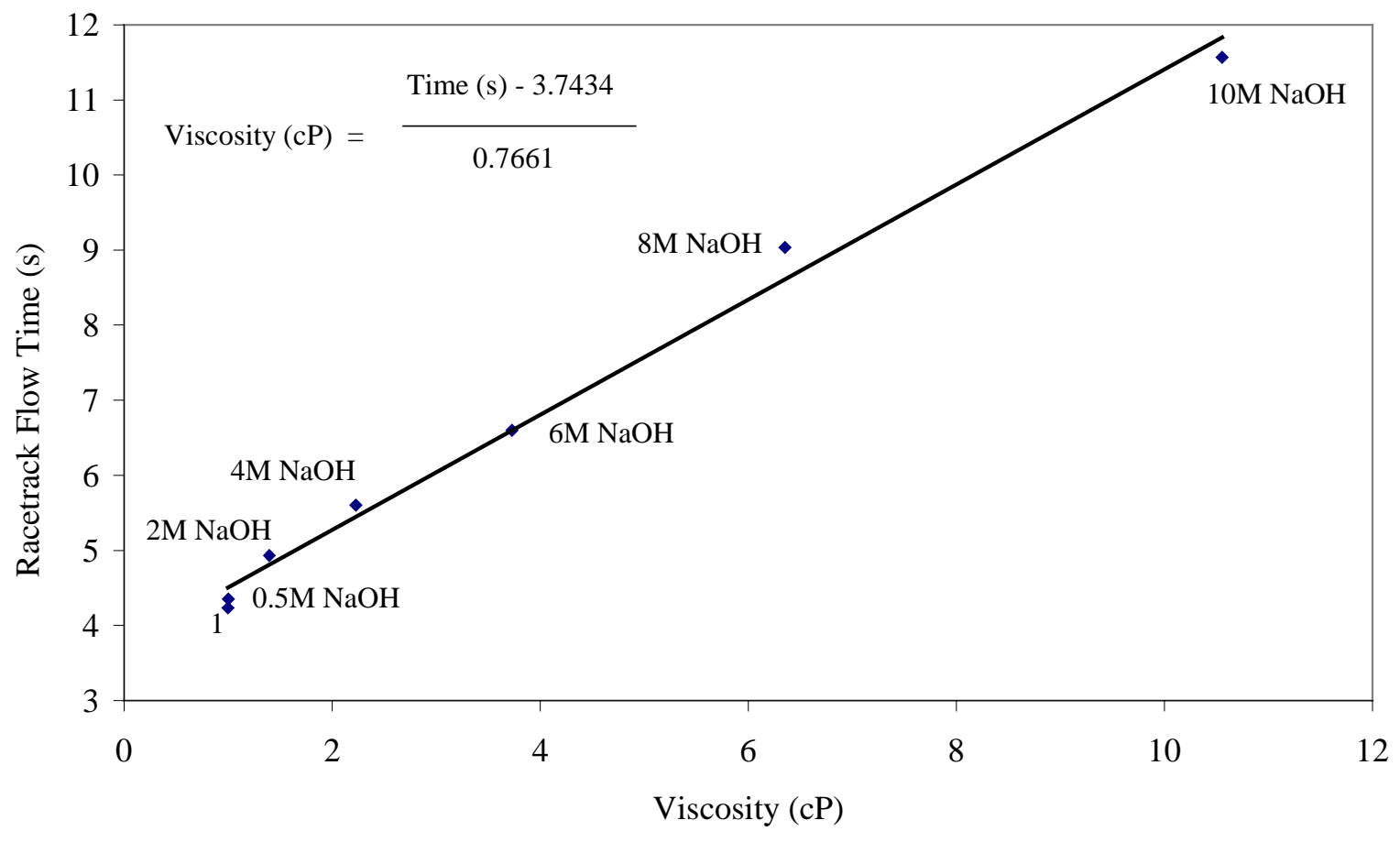

Figure C.2: Calibration curve for $\mathrm{NaOH}$ solutions in the Racetrack.

Table C.1: Viscosity of $\mathrm{NaOH}$ Solutions ${ }^{*}$

\begin{tabular}{cc}
\hline \hline & \\
$\mathrm{NaOH}, \mathrm{M}$ & Viscosity $(\mathrm{cP})$ \\
\hline 0.5 & 0.997 \\
2.0 & 1.396 \\
4.0 & 2.228 \\
6.0 & 3.727 \\
8.0 & 6.351 \\
10.0 & 10.554 \\
${ }^{*}$ CRC Handbook of Chemistry and Physics, $83^{\text {rd }}$ Edition, 2003.
\end{tabular}

